\title{
CONSUMER PREFERENCE AND WILLINGNESS TO PAY FOR AN OFFICIALLY CERTIFIED QUALITY LABEL: IMPLICATIONS FOR TRADITIONAL FOOD PRODUCERS
}

\section{Preferencia y disposición del consumidor a pagar por un sello de calidad certificada: Implicancias para productores de alimentos de origen campesino}

\author{
Carlos Padilla ${ }^{1}$, Pablo Villalobos ${ }^{1}$, Achim Spiller ${ }^{2}$ and Guy Henry ${ }^{3}$
}

\begin{abstract}
A B S T R A C T
A study was carried out in Chile in order to evaluate consumer preference and willingness to pay for a certified quality label on traditional food products, employing a conjoint analysis method. A total of 234 individuals were interviewed in two Chilean cities, Santiago and Talca. A homemade blackberry (Rubus ulmifolius) marmalade and three product attributes with their respective levels were chosen (price, quality label and jar appearance). Nine hypothetical product concepts were generated applying an orthogonal design. Respondents were asked to rank the product concepts according to their preferences. The results obtained through the conjoint model suggest that an "officially certified quality label" is the most important attribute influencing consumer choice behavior. Likewise, a positive willingness to pay for such an attribute is observed. As a differentiation and quality management tool, an official certified quality label seems to be a good alternative to improve the situation and market opportunities for small farmers. It is important to notice that this study corresponds to the first empirical approach carried out in Chile, which relates the conjoint analysis method with consumer preferences for this kind of food product.
\end{abstract}

Key words: quality attributes, certified quality label, product differentiation, conjoint analysis.

\section{R E S U M E N}

Con el objetivo de evaluar la preferencia y disposición a pagar del consumidor chileno por un sello de calidad certificada usado en productos alimenticios de origen campesino, se llevó a cabo un estudio empleando la metodología de análisis conjunto. Un total de 234 consumidores de las ciudades de Talca y Santiago fueron consultados, respondiendo un cuestionario especialmente diseñado. Como producto base para el análisis conjunto se utilizó una mermelada de mora (Rubus ulmifolius) de elaboración artesanal. Además, un conjunto de tres atributos (precio, sello de calidad y presentación del envase) fueron considerados en la evaluación. Mediante un diseño ortogonal, se definieron nueve conceptos de productos hipotéticos, los cuales fueron ordenados por los consumidores de acuerdo a sus preferencias. Los resultados obtenidos a través del modelo conjunto señalan que un "sello de calidad certificada" es el atributo más importante que domina el comportamiento de elección de los consumidores, observándose una positiva disposición a pagar por esta característica. Como herramienta de gestión de calidad y diferenciación, un sello de calidad certificada parece ser una buena alternativa para mejorar las condiciones y oportunidades de mercado de los productores de alimentos respaldados por una tradición campesina. Cabe destacar que ésta es la primera experiencia empírica desarrollada en el país que relaciona el método de análisis conjunto con las preferencias del consumidor por este tipo de productos alimenticios.

Palabras clave: atributos de calidad, sello de calidad certificada, diferenciación, análisis conjunto.

\footnotetext{
${ }^{1}$ Universidad de Talca, Facultad de Ciencias Agrarias, Casilla 747, Talca, Chile.

E-mail: cpadillab@utalca.cl *Autor para correspondencia.

${ }^{2}$ Georg-August Universität Göttingen, Department of Agricultural Economics and Rural Development, Platz der Göttinger Sieben 5, 37073, Göttingen, Alemania.

${ }^{3}$ Centre de Coopération Internationale en Recherche Agronomique pour le Développement. ProsPer Cône sud, c/o INTA, Cerviño 3101 (1425), Buenos Aires, Argentina.

Received: 17 March 2006.

Accepted: 1 June 2006.
} 


\section{INTRODUCTION}

Currently, the satisfaction of social and psychological consumers needs is increasingly driving the product development process, owing mainly to changes in the consumption patterns of the population and the optimization of physiological needs (Sijtsema et al., 2002). In high income countries it has been determined that a complex set of factors has changed consumer buying patterns (Senauer, 1995; 2001; Kinsey et al., 1996). Changes in demographic and socio-cultural variables, consumer attitudes and the development of new lifestyles define the consumer preferences for food. Added to this, in recent years consumers have lost confidence in relation to the quality of food products, as a result of numerous scandals and crisis that have affected the food industry.

Given this, industrialized countries are implementing new food policies, with the objective of protecting consumers from possible frauds and crisis (Spiller, 2003; Jahn et al., 2005). These policies have been translated into the design of instruments, both of a public and private character, to guarantee the quality and safety of food products. Among these instruments are the use of certified labels or seals that guarantee determined differentiating attributes of a product (Oyarzún and Tartanac, 2002). The use of quality labels or seals has brought a "new" attribute into the consumer choice process at the moment of purchasing (Walley et al., 1999). At the same time, the instruments of quality management, such as labels and seals, have been able to transform quality aspects to actively sought food attributes, facilitating the consumer purchasing process (Fotopoulos and Krystallis, 2003).

This has produced an extremely complex scenario in which consumers, for their part, are demanding new food products that are more sophisticated and safe, while private businesses and the public sector make innumerable efforts to recover credibility and consumer confidence. Doubtlessly, those most affected by this new food scenario have been the small scale producers and processors, since they have had to confront additional costs related to quality assurance and the implementation of new marketing systems for their products. Nevertheless, the development of traditional food products represents a good business opportunity for those same small scale rural businesses, given that their products are characterized by the presence of a series of attributes that differentiate them from the mass produced food products in a manner that makes them more attractive to consumers (Universidad de Chile, 2002). In this research, the "traditional food" concept is defined as those products elaborated by inhabitants of rural zones who employ traditional production methods and recipes. Likewise, the elaboration of these products is characterized by use of natural raw materials, a low level of industrialization and a low presence of chemical additives in the end product.

It is important to note that diverse empirical studies have documented that certain market segments are willing to pay a higher price for food products when these contain particular differentiating quality attributes (Misra et al., 1991; Alvensleben and Schrader, 1999; Sánchez and Gil, 1998; Govindasamy and Italia, 1999; Grannis et al., 2001; Jolly, 1999; Cowan et al., 2000; Grannis et al., 2000; Loureiro and Umberger, 2003; Villalobos, 2005). Nevertheless, at a national level the quality and safety of food products originating from small scale agriculture has been questioned by consumers, owing fundamentally to the absence of guarantee signals and quality certification. On the other hand, the lack of information in the Chilean market with regard to consumer preferences and willingness to pay for traditional food products makes decision making difficult for small family businesses in the rural sector, thus directly affecting the development of effective and efficient marketing strategies for this type of foods.

The main objective of this study was to contribute with market information that permits implementing an efficient and effective strategic marketing plan for traditional food products. Particularly, this study seeks: i) to analyze consumer preferences for an officially certified quality label, ii) to quantify the willingness to pay (WTP) of Chilean consumers for this quality indicator, and iii) to establish the implications for small scale food producers.

\section{MATERIALS AND METHODS}

\section{Target population}

The target population selected for this study were households belonging to the socio-economic segments $\mathrm{ABC} 1, \mathrm{C} 2$ and $\mathrm{C} 3$ in the cities of Talca 
and Greater Santiago. This segmentation owed to the fact that traditional food products tend to be of a more exclusive character and, in consequence, have a higher price than mass produced foods. They are, therefore, affordable to socio-economic groups with higher incomes. The inclusion in this study of a sample of consumers from Santiago, Chile's capital city, and from Talca, the capital city of the Maule Region, reflected the purpose of knowing and analyzing the average Chilean consumer behavior towards traditional food products.

\section{Sample selection and data collection}

The selected design to carry out this research was of a quantitative-descriptive character. The selected method to gather the data analyzed in this study was a survey, while the instrument applied was a questionnaire structured in four sections, which was administered in a face to face interview The first section of the questionnaire included questions of a general character about the consumption of food products, the second section included the analysis of preferences, the third incorporated questions about consumerbehavior towards traditional food products and, finally, the fourth section sought socio-economic information about the respondents. The sample was selected for convenience through personal contacts with consumers from the aforementioned socio-economic levels. This facilitated conducting the interviews directly in homes and offices in Talca and Santiago. In this research, the sample should be considered as non-probabilistic, a non-probabilistic sample being one in which the probability of selecting members of the population is unknown (Aaker et al., 2003).

A total of 234 interviews were conducted throughout October and the first week of November, 2004, this being the maximum number of interviews that could be carried out by the surveyors (two in total) who participated in the data collection process. According to Cattin and Wittink (1982), the median sample size for studies that analyze consumer preference ranges between 100 and 1000 subjects. As a sample unit for this study were selected those persons in charge of making food purchases for their household, or at least those who participate in this activity. Previously to the interview, consumers were contacted with the objective of knowing their interest in participating in this research, and at the same time, in order to establish the most appropriate place (home or office) and time to carry out the interview. Over $90 \%$ of the persons contacted were willing to answer the questionnaire. Of the total number of interviews, 150 were carried out in Talca and 84 in Santiago. It should be noted that the time and budget to carry out this study were constraint factors to reach a greater number of interviewed subjects in Santiago. All of the questionnaires applied were considered valid for the data analysis section.

Before administering the questionnaire in both cities, a pilot study of the instrument was carried out in Talca, with the purpose of verifying the instrument's consistency and understanding. To carry out the pilot study 10 consumers willing to answer the questionnaire were contacted. After carrying out these interviews, a final version of the questionnaire was structured, taking into consideration the difficulties detected.

\section{Analysis of consumer preferences}

Conjoint analysis (CA) was the method used to investigate consumer preferences; this is defined as a decompositional method that disaggregates the structure of consumer preferences into utility values. As well, the method allows for estimating the relative importance of the attributes of a product (Green and Srinivasan, 1978; Harrison et al., 1998; 2001). CA is currently being used broadly in market research (Cattin and Wittink, 1982; Wittink and Cattin, 1989; Wittink et al., 1994; Green et al., 2001). The main reason for the recent popularity of $\mathrm{CA}$ is its high degree of flexibility to study a wide range of purchasing decisions involving many attributes (Harrison et al., 2001). The method allows for estimating part-worth utilities for each level of an attribute. In other words, this technique provides a utility function for each level of each attribute (Green and Wind, 1975). The estimated part-worth utilities indicate how influential each attribute level is in the formation of consumer preferences for a particular combination, that is, they represent the degree of consumer preference for each level of each attribute (Wang and Sun, 2003). To be valid in an analysis of preferences, the total utilities of each combination (product profile) should be highly correlated with the observed preferences, in other words, they should correspond to the original ranks as closely as possible (Green and Wind, 1975; Aaker et al., 2003).

\section{Selection of the attributes and construction of the stimulus}

For the purpose of this study the product "homemade blackberry marmalade" in glass containers (net weight of $500 \mathrm{~g}$ ) was selected. This choice was made taking 
into consideration the recommendations of specialists from the Institute of Agricultural Development (INDAP), who have experience in the promotion and sale of traditional food products through the program "Flavors of the Countryside" ("Sabores del Campo"). At the same time, with the support of specialists from INDAP, and taking into account an exploratory study carried out by the University of Chile (2002), three attributes were selected: price, quality label and jar appearance. In the case of the price attribute, three levels of value were determined. In the same manner, three levels were determined for the quality label attribute. In the case of the jar appearance attribute, an homemade appearance was considered (a jar with a piece of cloth attached to the upper part) and a conventional appearance (a jar without a piece of cloth). The levels selected for each attribute are shown in Table 1.

Given that three attributes with their respective levels were chosen, a full factorial design would include 18 hypothetical combinations $(3 \times 3 \times 2)$. Therefore, in order to reduce the number of product profiles to a manageable number for the respondents, an orthogonal design was generated with nine cards (product profiles) using SPSS Conjoint, 9.0 version (SPSS, 1997). Table 2 presents the nine combinations generated by the orthogonal design.

Likewise, in order to verify how well the conjoint model fits the data, two holdout cases were included.

Table 1. Label and attribute levels selected for the conjoint analysis.

Cuadro 1. Etiqueta y niveles de los atributos escogidos para el análisis conjunto.

\begin{tabular}{lll}
\hline Attribute & $\begin{array}{c}\text { Attribute } \\
\text { label }\end{array}$ & \multicolumn{1}{c}{$\begin{array}{c}\text { Attribute } \\
\text { level }\end{array}$} \\
\hline Price & Price & $\begin{array}{l}\text { Price } 1(\$ 1000)^{\mathrm{a}} \\
\text { Price } 2(\$ 1500)\end{array}$ \\
& & $\begin{array}{l}\text { Price } 3(\$ 2000) \\
\text { Quality label }\end{array}$ \\
& Quality label & $\begin{array}{l}\text { Without label } \\
\text { Label certified by INDAP } \\
\text { Label certified by SAG }\end{array}$ \\
Jar & Appearance & $\begin{array}{l}\text { Homemade } \\
\text { Conventional }\end{array}$ \\
\hline
\end{tabular}

a $\$$ Chilean pesos $(1 €=\$ 760$ Chilean pesos).

${ }^{\mathrm{b}}$ Instituto de Desarrollo Agropecuario (Institute of Agricultural Development).

c Servicio Agrícola y Ganadero. (Agricultural and Livestock Service).
Holdout cases are profiles that are judged by the subjects but are not used by the conjoint procedure to estimate utilities. They are generated from another random plan, not from the experimental orthogonal plan. They are used to compute correlations between the observed and predicted rank orders for the profiles, as a check on the validity of the utilities (SPSS, 1997).

In order to quantify part-worth utilities, the respondents were asked to sorta set of 11 photographic representations of the product profiles ( 9 cards plus 2 holdout cases), in terms of their preferences. Although the presentation of stimulus through photographic representations is not the most used technique (Cattin and Wittink, 1982; Wittink and Cattin, 1989), there is growing interest in it owing to the fact that it offers several advantages. Among these advantages can be noted the possibility of evaluating a greater number of attributes, it provides easier and potentially less ambiguous ways of conveying information, and it makes the task more entertaining and interesting to respondents, among others (Green and Srinivasan, 1990; Green et al., 2001).

\section{Specification of the conjoint model}

To estimate utilities, a part-worth model (additive function model) was employed (Green and Srinivasan, 1978; Cattin and Wittink, 1982; Wittink and Cattin, 1989; Green et al., 2001). Considering the attributes evaluated in this research, the overall preference or total utility of a combination (R) can be expressed through the following equation:

Table 2. Orthogonal design for homemade blackberry marmalade.

Cuadro 2. Diseño ortogonal para mermelada casera de mora.

\begin{tabular}{|c|c|c|c|}
\hline Card & $\operatorname{Price}(\$)^{a}$ & Quality label & Jar \\
\hline 1 & 1000 & Without label & Homemade \\
\hline 2 & 2000 & $\mathrm{SAG}^{\mathrm{b}}$ & Conventional \\
\hline 3 & 1500 & $\mathrm{INDAP}^{\mathrm{c}}$ & Homemade \\
\hline 4 & 1500 & Without label & Conventional \\
\hline 5 & 1500 & SAG & Homemade \\
\hline 6 & 2000 & INDAP & Homemade \\
\hline 7 & 1000 & SAG & Homemade \\
\hline 8 & 1000 & INDAP & Conventional \\
\hline 9 & 2000 & Without label & Homemade \\
\hline \multicolumn{4}{|c|}{$\begin{array}{l}\text { a Chilean pesos ( } 1 €=\$ 760 \text { Chilean pesos Chilean pesos). } \\
\text { b Instituto de Desarrollo Agropecuario (Institute of Agricultural } \\
\text { Development). } \\
\text { c Servicio Agrícola y Ganadero (Agricultural and Livestock } \\
\text { Service). }\end{array}$} \\
\hline
\end{tabular}


$R_{\mathrm{i}}=$ Uprice $_{\mathrm{i}}+$ Ulabel $_{\mathrm{j}}+$ Ujar $_{\mathrm{k}}+$ constant

where: uprice $_{i}=$ utility of the level $i$ for the price attribute, Ulabel $=$ utility of the level $j$ for the quality label attribute, $\operatorname{Ujar}_{k}=$ utility of the level $k$ for the jar appearance attribute.

For the price attribute, a linear function form was established. This is because generally, the higher the price, the lower the utility or preference. The other attributes were assumed as discrete variables. Therefore, the econometric representation of the conjoint model is the following:

$R_{\mathrm{i}}=\beta_{0}+\beta_{1} P+\beta_{2} S C_{1}+\beta_{3} S C_{2}+\beta_{4} A E+e_{\mathrm{i}}$

where: $R_{i}$ represents the preference rank order established by the $\mathrm{i}^{\text {th }}$ individual surveyed, $P$ is the price variable, $S C_{1}=1$ and $S C_{2}=0$ represent the quality label certified by SAG (Agricultural and Livestock Service), $S C_{1}=0$ and $S C_{2}=1$ represent the quality label certified by INDAP (Institute of Agricultural Development), $S C_{1}=-1$ and $S C_{2}=-1$ represents the level without a quality label, $A E=1$ corresponds to a home made appearance, $A E=0$ is a conventional appearance, $\beta_{0}$ is the regression constant; $\beta_{1}, \beta_{2}, \beta_{3}$ are the part-worth utilities associated with the levels of each attribute, and $e_{i}$ is the error term.

\section{RESULTS AND DISCUSSION}

\section{Sample description}

In this study 234 individuals were interviewed. All of the questionnaires gathered were considered valid for the data analysis procedure. Table 3 presents a summary of the main sample's characteristics. The analysis of the sample indicates that it was biased towards female respondents. This would indicate that women are mainly responsible of buying the foodstuffs consumed by the household. The socio-economic group "C2" and the educational level "University" tend to be overrepresented in the sample with respect to population statistics.

Table 4. Utilities estimated by the conjoint model. Cuadro 4. Utilidades estimadas por el modelo conjunto.
Table 3. Sample description. Study of consumer preferences.

Cuadro 3. Descripción de la muestra. Estudio preferencias de los consumidores.

\begin{tabular}{lc}
\hline Variable & Percentage \\
\hline Gender & \\
$\quad$ Male & 32.9 \\
$\quad$ Female & 67.1 \\
Age & \\
$\quad 35$ or less & 30.8 \\
$\quad$ Between 36 and 57 & 57.3 \\
$\quad$ Over 57 & 12.0 \\
Monthly family income $(\$)^{\mathrm{a}}$ & \\
$\quad$ 650 000 or less $(\mathrm{C} 3)$ & 26.9 \\
$\quad$ Between 650001 and $1850000(\mathrm{C} 2)$ & 56.8 \\
$\quad$ Over 1 850 000 (ABC1) & 16.2 \\
Education & \\
$\quad$ Elementary or secondary & 10.0 \\
$\quad$ Technical school & 18.8 \\
$\quad$ University & 70.5 \\
Household size & \\
$\quad$ 1 person & 5.6 \\
$\quad$ Between 2 and 4 persons & 70.9 \\
$\quad$ More than 4 persons & 23.5 \\
\hline
\end{tabular}

${ }^{\mathrm{a}} \$$ Chilean pesos $(1 €=\$ 760$ Chilean pesos $)$.

\section{Conjoint analysis for homemade blackberry marmalade}

The estimation of part-worth utilities for each level of each attribute and the relative importance of the assessed attributes are presented below.

\section{a) Part-worth utilities}

Table 4 shows that the quality label certified by SAG achieves the highest utility score for this attribute (1.219). This indicates that in some way consumers trust more in this institution, which could be explained because the average citizen would be much more informed about the functions carried out by SAG as official inspection institution body in terms of vegetable and animal sanitation and certification at a national level. In the case of the jar appearance attribute, the homemade type achieves the highest utility score (0.444). Finally, the lowest price yields the highest utility score, which is in agreement with economic theory.

\begin{tabular}{ccccccc}
\hline Constant & $\begin{array}{c}\text { Without } \\
\text { label }\end{array}$ & $\begin{array}{c}\text { INDAP } \\
\text { label }^{\mathbf{a}}\end{array}$ & $\begin{array}{c}\text { SAG } \\
\text { label }^{\mathbf{b}}\end{array}$ & $\begin{array}{c}\text { Homemade } \\
\text { appearance }^{2}\end{array}$ & $\begin{array}{c}\text { Conventional } \\
\text { appearance }\end{array}$ & $\begin{array}{c}\text { Price } \\
\left(\boldsymbol{\beta}_{1}\right)\end{array}$ \\
\hline 7.992 & -2.003 & 0.784 & 1.219 & 0.444 & -0.444 & -1.594 \\
\hline
\end{tabular}

${ }^{a}$ Instituto de Desarrollo Agropecuario (Institute of Agricultural Development).

${ }^{\mathrm{b}}$ Servicio Agrícola y Ganadero (Agricultural and Cattle Service). 
The internal validity of the model is estimated by means of the Kendall's tau-b statistic (Green and Srinivasan, 1978; Hair et al., 1999). The value obtained for this coefficient $(0.944$; with a level of significance of $p$ equal to 0.0002 ), shows that there is a strong correlation between the observed preferences and those estimated by the conjoint model. The predictive validity of the model is estimated by calculating the Kendall's tau-b between the observed rankings and those estimated for the holdout cards. The Kendall's tau-b value obtained in this case was 1.0 ; with a level of significance of $p$ equal to 0.0000 . The preceding suggests the high predictive validity of the model.

The total utilities of each product profile (evaluated cards) are shown in Table 5. In this case, card seven achieves the highest total utility (price $=\$ 1000$, quality label $=$ certified by SAG, jar appearance $=$ homemade). On the other hand, the lowest score was obtained by card nine (price $=\$ 2000$, quality label $=$ without quality label, jar appearance $=$ homemade). For more details about the other cards see Table 2.

\section{b) Relative importance of the attributes}

The estimated part-worth utilities can also be used to calculate the relative importance of the attributes of a particular product. According to Halbrendt et al. (1995), the relative importance weights (RI) can be calculated as follows: first, the highest and lowest part-worth utilities are determined for each attribute. The difference between the highest and lowest partworth establishes the utility range for each attribute. Once a range for each attribute has been determined, the relative importance of the $\mathrm{i}^{\text {th }}$ attribute is calculated by dividing the range of the $\mathrm{i}^{\text {th }}$ attribute by the sum of all ranges. This procedure is calculated through the following equation:

$R I_{\mathrm{i}}=\left[\frac{\text { Utility range }_{\mathrm{i}}}{\sum \text { Utility ranges } \forall \text { attributes }}\right] * 100$

The scores of relative importance can be observed in Table 6. In this study, the certified quality label attribute is the most important, with $49.55 \%$. The second attribute
Table 6. Summary of relative importance of the attributes.

Cuadro 6. Resumen de la importancia relativa de los atributos.

\begin{tabular}{lc}
\hline Attribute & Relative importance \\
\hline Quality label & 49.55 \\
Price & 33.86 \\
Jar appearance & 16.59 \\
\hline
\end{tabular}

in importance is price (33.86\%), while the jar appearance is the least important attribute $(16.59 \%)$. This means that consumer choice behavior is mainly being guided by the attribute quality label. This confirms what has been pointed out in previous studies, in which it has been determined that the presence of an instrument or indicator that guarantees the quality of the product significantly affects consumer preference structure (Misra et al., 1991; Souza Monteiro and Ventura, 2001; Schupp and Gillespie, 2001).

Although the price attribute negatively affects consumer utility (negative value $\beta_{1}$ ), this can be offset through the use of a certified quality label. In other words, producers of traditional food products could increase the price of their products using an indicator of certified quality, without fear of losing market share as a result of a price increase. As well, the use of an instrument of quality management, like a certified quality label, can bring a competitive advantage by means of product differentiation, which could be considered as a marketing strategy similar to branding (Fotopoulos and Krystallis, 2003). In the same manner, these guarantees of certified quality provide protection from competition through the creation of market niches and quality/price advantages (Marreiros et al., 1997).

As a tool for quality management and differentiation, a certified quality label seems to be a good alternative to improve market conditions and opportunities for small scale producers and processors of traditional food products. However, to meet this objective, the strategy of differentiation through a certified quality

Table 5. Total utilities of the product profiles (evaluated cards) ${ }^{1}$. Cuadro 5. Utilidad total de los perfiles de producto (tarjetas evaluadas) ${ }^{1}$.

\begin{tabular}{cccccccccc}
\hline & \multicolumn{10}{c}{ Cards } \\
\cline { 2 - 10 } & $\mathbf{1}$ & $\mathbf{2}$ & $\mathbf{3}$ & $\mathbf{4}$ & $\mathbf{5}$ & $\mathbf{6}$ & $\mathbf{7}$ & $\mathbf{8}$ & $\mathbf{9}$ \\
\hline Total utility & 4.35 & 4.57 & 6.08 & 2.40 & 6.52 & 5.03 & 7.57 & 6.24 & 2.24 \\
\hline
\end{tabular}

${ }^{1}$ Table 2 describes each card. 
label implies not only the implementation of communication campaigns, but also the organization and association of small producers. In relation to this last point, the role of the public sector as a source of technical and financial assistance becomes a key factor.

\section{Marginal willingness to pay for the "certified quality label" attribute}

Based on the results of the CA, the marginal willingness to pay (MWTP) was estimated for the attribute quality label certified by SAG. According to Gan and Luzar (1993), the MWTP is the negative quotient between the utility value of each attribute level (in this case the quality label certified by SAG) and the coefficient of the price attribute (valor $\beta_{1}$ ). The calculation procedure is shown in the following equation:

$M W T P=-\left(\frac{\text { Utility SAG label }}{\beta_{1} \text { price }}\right)$

The results indicated that consumers would be willing to pay $\$ 585$ pesos $(1 €=\$ 760$ Chilean pesos) more for homemade marmalade with a quality label certified by SAG, over the price of a product without a quality label. If, for example, the average market price ( $\$ 1500$ in a $500 \mathrm{~g}$ glass jar) paid for homemade marmalade without a quality certification is taken into consideration, it can be said that the surveyed subjects would be willing to pay $39 \%$ more for a homemade marmalade guaranteed with a certified quality label. In general, the respondents showed a positive willingness to pay for a guarantee of certified quality. This finding supports what has been documented in previous studies, in which consumers were shown to be willing to pay a higher price for those products characterized by differentiating quality attributes (Misra et al., 1991; Alvensleben and Schrader, 1999; Sánchez and Gil, 1998; Govindasamy and Italia, 1999; Grannis et al., 2001; Jolly, 1999; Cowan et al., 2000; Grannis et al., 2000; Loureiro and Umberger, 2003; Villalobos, 2005). However, the high willingness to pay obtained in this study can, in some measure, be biased by the price levels used in the preference analysis. Taking into consideration the respondents' socio-economic segments, prices of $\$ 1000$ or $\$ 1500$ for homemade marmalade in a $500 \mathrm{~g}$, glass jar could be considered low. This fact should be taken into account by authors who plan to implement similar studies using the CA methodology.
In the particular case of this study, it must be kept in mind that to estimate the utilities of each attribute, price levels used in the estimation of the conjoint model were expressed in terms of Euros $(1 €=\$ 760$ Chilean pesos). Therefore, the result of equation 4 must be multiplied by $\$ 760$, which corresponds to the average value of the European currency recorded during December, 2004.

Finally, keeping in mind the limitations of this research it is required, on one hand, to corroborate the results presented in this study through the implementation of similar and complementary researches, that allow for inferring generalizations and contribute to increase knowledge about the use of instruments of quality management. On the other hand, the preference structure of Chilean consumers for other types of attributes of traditional food products should be studied, with the goal of providing a wider idea about their preferences. Likewise, identifying the variables that influence consumer willingness to pay and the formation of the consumer preference structure should be topics of discussion in future researches.

\section{CONCLUSIONS}

Estimation of the relative importance of the attributes evaluated in this study shows the major impact that a certified quality label has on the consumer choice behavior. In the particular case of this research, the quality label certified by SAG achieved a high level of utility.

Consumers would be willing to pay more for a traditional food product with a certified quality label, than for a product without one. Therefore, the small scale producers and processors of this type of food should consider this attribute as a strategic tool for differentiation.

While the results of the conjoint model show a tendency, they should be understood as the potential that a well advertised and promoted certified label might achieve. Therefore, communication and promotional campaigns are necessary to educate consumers, with the purpose of getting consumer recognition and confidence on the quality indicator used. 


\section{LITERATURE CITED}

Aaker, D., V. Kumar, and G. Day. 2003. Marketing research. 800 p. $7^{\text {th }}$ ed. John Wiley and Sons, New York, USA.

Alvensleben, R., and S. Schrader. 1999. Consumer attitudes towards regional food products: a case-study for Northern Germany. The European Food Consumer 5:10-19.

Cattin, P., and D. Wittink. 1982. Commercial use of conjoint analysis: a survey. J. Marketing 46:44-53.

Cowan, C., N. Riordan, and M. McCarthy. 2000. Irish consumers' willingness to pay for safe beef. p. 14 . The National Food Centre, Dublin, Ireland.

Fotopoulos, C., and A. Krystallis. 2003. Quality labels as a marketing advantage: the case of the "PDO Zaragoza" apples in the Greek market. Eur. J. Marketing 37:1350-1374.

Gan, C., and E. Luzar. 1993. A conjoint analysis in waterfowl hunting in Louisiana. J. Agric. Appl. Econ. 25:36-45.

Govindasamy, R., and J. Italia. 1999. Predicting willingness to pay a premium for organically grown fresh produce. J. Food Distrib. Res. 30:44-53.

Grannis, J., S. Hine, and D. Thilmany. 2001. Marketing premium food products in emerging economies: the case of Macedonian cheese. J. Int. Food Agribus. Mark. 13:59-76

Grannis, J., N. Hooker, and D. Thilmany. 2000. Consumer preference for specific attributes in natural beef products. p. 13. Western Agricultural Economics Association Annual Meeting, Vancouver, British Columbia, Canada. June 29-July 01. Western Agricultural Economics Association, Vancouver, British Columbia, Canada.

Green, P., A. Krieger, and Y. Wind. 2001. Thirty years of conjoint analysis: reflections and prospects. Interfaces 31:56-73.

Green, P., and V. Srinivasan. 1978. Conjoint analysis in consumer research: issues and outlook. J. Consum. Res. 5:103-123.

Green, P., and V. Srinivasan. 1990. Conjoint analysis in marketing: new developments with implications for research and practice. J. Marketing 54:3-19.

Green, P., and Y. Wind. 1975. New way to measure consumers' judgments. Harvard Business Review 53:107-117.

Hair, J., R. Anderson, R. Tatham, y W. Black. 1999. Análisis multivariante. 832 p. $5^{\text {a }}$ ed. Prince Hall Iberia, Madrid, España.

Halbrendt, C., Q. Wang, C. Fraiz, and L. O'Dierno. 1995. Marketing problems and opportunities in mid-Atlantic seafood retailing. Am. J. Agric. Econ. 77:1313-1318.
Harrison, R., J. Gillespie, and D. Fields. 2001. Theoretical and empirical considerations of eliciting preferences and model estimation in conjoint analysis. p. 17. American Agricultural Economics Association Annual Meeting, Chicago, Illinois, USA. August 58. American Agricultural Economics Association, Chicago Illinois, USA.

Harrison, R., A. Özayan, and S. Meyers. 1998. A conjoint analysis of new food products processed from underutilized small crawfish. J. Agric. Appl. Econ. 30:257-265.

Jahn, G., M. Schramm, and A. Spiller. 2005. The reliability of certification systems: quality labels as consumer policy tool. J. Consum. Policy 28:53-73.

Jolly, D. 1999. "Home Made" the paradigms and paradoxes of changing consumer preferences: implications for direct marketing. p. 8. Agricultural Outlook Forum, Arlington, Virginia, USA. February 22-23. United States Department of Agriculture, Washington, DC, USA.

Kinsey, J., B. Senauer, R. King, and P. Phumpiu. 1996. Changes in retail food delivery: signals for producers, processors and distributors. Working Paper 96-03. p. 36. The Retail Industry Center, University of Minnesota, Saint Paul, Minnesota, USA.

Loureiro, M., and W. Umberger. 2003. Estimating consumer willingness to pay for country of origin labeling. J. Agr. Resour. Econ. 28:287-301.

Marreiros, C., M. Neto, and L. Carvalho. 1997. Certification of agro-food quality products: a new reality in demand and farm management. p. 11. European Association of Agricultural Economist Seminar, 52 nd, Parma, Italy. 19-21 June. University of Parma, Parma, Italy.

Misra, S., C. Huang, and S. Ott. 1991. Consumer willingness to pay for pesticide-free fresh produce. West. J. Agric. Econ. 16:218-227.

Oyarzún, M., y F. Tartanac. 2002. Estudio sobre los principales tipos de sellos de calidad en alimentos a nivel mundial. Estado actual y perspectivas de los sellos de calidad en productos alimenticios de la agroindustria rural en América Latina. p. 70. FAO, Santiago, Chile.

Sánchez, G., y G. Gil. 1998. Evaluación del potencial de mercado de los productos de agricultura ecológica. Rev. Esp. Invest. Marketing 2:135-150.

Schupp, A., and J. Gillespie. 2001. Consumer attitudes towards potential country of origin labelling of fresh or frozen beef. J. Food Distrib. Res. 32:34-44. 
Senauer, B. 1995. The evolution of an industrialized, globalized, consumer-driven food system. Working paper 95-3. p. 14. Minnesota Padova Conference on Food Agriculture and Environment, $4^{\text {th }}$, Wayzata, Minnesota, USA. September 4-10. University of Minnesota, Center for International Food and Agricultural Policy, Saint Paul, Minnesota, USA.

Senauer, B. 2001. The food consumer in the 21 st century. New research perspectives. Working Paper 01-03. p. 25. The Retail Industry Center. University of Minnesota, Saint Paul, Minnesota, USA.

Sijtsema, S., A. Linnemann, T. Van Gaasbeek, H. Dagevos, and W. Jongen. 2002. Variables influencing food perception reviewed for consumer-oriented product development. CRC Crit. Rev. Food Sci. Nutr. 42:565-581.

Souza Monteiro, D., and M. Ventura. 2001. Conjoint measurement of preferences for traditional chesses in Lisbon. Br. Food J. 103:414-424.

Spiller, A. 2003. Nuevas orientaciones para el aseguramiento de la calidad en la cadena agroalimentaria. p. 34-66. In Conferencia Internacional sobre Gestión de la Calidad en la Cadena Agroalimentaria, Santiago, Chile. Marzo de 1998. Instituto Interamericano de Cooperación para la Agricultura (IICA), Santiago, Chile.

SPSS. 1997. SPSS Conjoint 8.0. Marketing Department, SPSS Inc. Available at http://www.spss.com Accessed January 20, 2005.
Universidad de Chile. 2002. Bases para la especificación técnica "Especialidad Campesina Garantizada". Informe final. 124 p. Universidad de Chile, Facultad de Ciencias Agronómicas, Santiago, Chile.

Villalobos, P. 2005. Bienestar animal como atributo de diferenciación en la decisión de compra de los consumidores. p. 139-147. In G. González et al. (eds.). Actas del Seminario "La institucionalidad del bienestar animal, un requisito para su desarrollo normativo, científico y productivo", Santiago, Chile. 11-12 de noviembre de 2004. Servicio Agrícola y Ganadero, Santiago, Chile.

Walley, K., S. Parsons, and M. Bland. 1999. Quality assurance and the consumer: a conjoint study. Br. Food J. 101:148-162.

Wang, Q., and J. Sun. 2003. Consumer's preference and demand for organic food: evidence from a Vermont survey. p. 12. American Agricultural Economics Association Annual Meeting, Montreal, Canada. July 27-30. American Agricultural Economics Association, Montreal, Canada.

Wittink, D., and P. Cattin. 1989. Commercial use of conjoint analysis: an update. J. Marketing 53:91-96.

Wittink, D., M. Vriens, and W. Burhenne. 1994. Commercial use of conjoint analysis in Europe: results and critical reflections. Int. J. Res. Mark. 11:41-52. 